\title{
On the Performance of Hybrid PV/Unitized Regenerative Fuel Cell System in the Tropics
}

\author{
Salwan Dihrab, ${ }^{1}$ Tamer Khatib, ${ }^{2}$ Kamaruzzaman Sopian, ${ }^{3}$ \\ Habeeb Al-Ani, ${ }^{3}$ and Saleem H. Zaidi ${ }^{3}$ \\ ${ }^{1}$ Center of Renewable energy, Universiti Tenaga Nasional, Bangi 43000, Selangor, Malaysia \\ ${ }^{2}$ Department of Electrical, Electronic \& System Engineering, Faculty of Engineering \& Built Environment, \\ Universiti Kebangsaan Malaysia, Bangi 43600, Selangor, Malaysia \\ ${ }^{3}$ Solar Energy Research Institute, Universiti Kebangsaan Malaysia, Bangi 43600, Selangor, Malaysia
}

Correspondence should be addressed to Tamer Khatib, tamerkhat@hotmail.com

Received 20 August 2012; Revised 21 October 2012; Accepted 31 October 2012

Academic Editor: Tapas Mallick

Copyright (๑) 2012 Salwan Dihrab et al. This is an open access article distributed under the Creative Commons Attribution License, which permits unrestricted use, distribution, and reproduction in any medium, provided the original work is properly cited.

\begin{abstract}
Solar hydrogen system is a unique power system that can meet the power requirements for future energy demands. Such a system uses the hydrogen as the energy carrier, which produces energy through the electrolyzer with assistance of the power from the PV during the sunny hours, and then uses stored hydrogen to produce energy through the fuel cell after sunset or on cloudy days. The current study has used premanufactured unitized regenerative fuel cells in which the electrolyzer and the fuel cell function within one cell at different modes. The system components were modeled and the one-day real operational and simulated data has been presented and compared. The measured results showed the ability of the system to meet the proposed load, and the total efficiency was about $4.5 \%$.
\end{abstract}

\section{Introduction}

Photovoltaic (PV) power generation, which directly converts solar radiation into electricity, contains a lot of significant advantages, such as being inexhaustible and pollution-free, silent and with no rotating parts, and its size-independent electricity conversion efficiency. A positive environmental effect of photovoltaic is replacing electricity generated in a more pollutant way, or providing electricity where none was available before. While increasing the penetration of solar photovoltaic devices, various antipollution apparatuses can be operated by solar PV power, for example, water purification by electrochemical processing or stopping desert expansion by photovoltaic water pumping with tree implantation [1].

The hybrid PV/hydrogen systems have units producing hydrogen called electrolyzers, which are used to generate hydrogen with the assistance of the PV as an energy source. This hydrogen will be preserved in suitable storage medium before being converted to DC power through a unit called fuel cell. Fuel cells are electrochemical devices that convert chemical energy, typically from hydrogen, directly into electrical energy. The introduction of fuel cell systems into the power generation market will not only supply clean renewable energy to millions of users, but it will help to reduce the dependence on oil [2].

Such a system includes a source of power (PV modules), a hydrogen generator (electrolyzer), a storage medium to store the hydrogen and hydrogen utilization units (fuel cell) which are able to make a continuous, and self-dependant or uninterruptable source of energy. The PV size should be designed properly, in order to have excess power over the load requirement. This excess power will be used to generate hydrogen through the generation units, and it will then utilize it after sunset or at a time of low solar irradiation. The load in this system will be powered in the short-term by the PV modules, and the hydrogen system will act as a long-term supplier. An illustration of short- and long-term supplying is shown in Figure 1.

The modeling of a PV-powered hydrogen generation system is needed to solve the electrical equations for the PV and the DC/DC converters (if they exist) and the electrochemical 


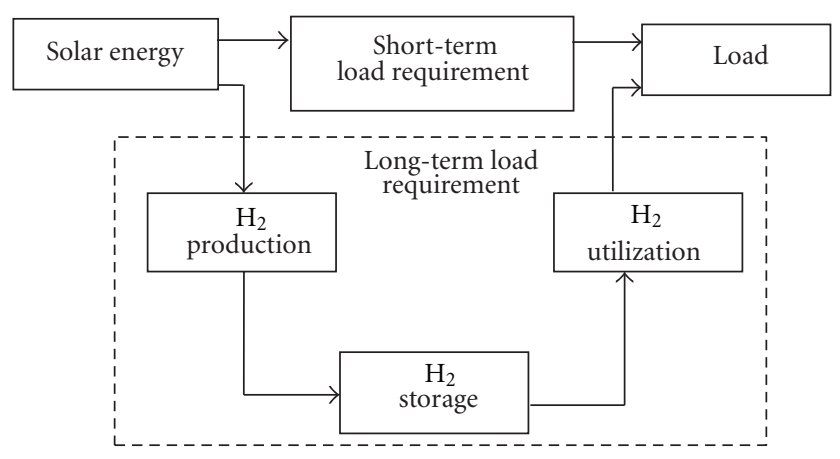

FIGURE 1: Long- and short-term power supplying for solar hydrogen systems [3].

equation for the electrolyzers. Fischer [4] compared the experimental results of a small system consisting of a solar cell generator, water electrolysis, and power conditioning with calculated results of a system simulation model, while Vidueira et al. [5] examined the performance of the solar hydrogen system for producing hydrogen via an electrolysis generator, in order to satisfy the hydrogen consumption of the first two fuel cell buses in Madrid. Some other researchers used various software to simulate the system performance, such as Park et al. [6, 7], who used (PSCAD/EMTDC) software to simulate a hydrogen production system performance.

Galli and Stefanoni [8] investigated and tested some commercial solar-hydrogen technologies, preliminary performance results, and the control of the system for solarpowered regenerative fuel cell system in Italy, while Hedström et al. [9] did so in Sweden, Abaoud and Steeb [10] in the German-Saudi bilateral program HYSOLAR, Voss et al. [11] in Germany, Lutfi and Veziroğlu [12] in Pakistan, Chaparro et al. [13] in Spain, and Little et al. [14] in UK. Torres et al. [15] also simulated a PV-hydrogen-fuel-cell hybrid system in Mexico.

The main objective of this paper is to present the performance of a hybrid PV/unitized regenerative fuel cell system under Malaysian weather conditions. A PV/unitized regenerative fuel cell system is built in the laboratories of the solar energy research institute (SERI)/Universiti Kebangsaan Malaysia. The results presented in this paper are based on a real operation conditions. The comparison between the operational and simulated data is also presented in this paper.

\section{System Description}

The proposed system mainly consists of two major subsystems, which are the PV modules (Kyosera, KC85T) located outdoor and the hydrogen system located inside the lab. The main components of the system used in this work are 3 same oriented PV modules (the method used by Markvart [16] is based on the maximum operating current, and the lowest solar irradiation was used to predict how many modules needed to be used) with $87 \mathrm{~W}$ maximum power and $0.65 \mathrm{~m}^{2}$ active area, unitized regenerative fuel cell (URFC), gases storages and water tanks, humidifiers, water traps, DC/DC converter (WD150-400), maximum power point tracker
(MPPT) (STECA PR 1010) to ensure maximum PV power output, and bus bar to transfer the current either from the PV to the load and electrolyzer in the sunny hours or from the fuel cell to the load during the sunset. The system starts in the morning, when the PV current is high enough to power the load, while the excess current sends power to URFC stack, which works in electrolysis mode, receiving water from small water pump. The generated gases are then sent to the storage tanks. When the PV current fails to power the load, the system will then switch to fuel cell mode after purging the lines with nitrogen. The humidifiers used for fuel cell mode were PERMA PURE MH Series humidifiers which are shell and tube moisture exchangers that allow the transfer of water vapor between a liquid water supply and a flowing gas stream. Water is absorbed into the walls of the Nafion tube and transferred to the dry gas stream. This transfer is driven by the difference in partial pressures of water vapor on opposing sides. Deionized water was filled into the tank which is equipped with heater $(2 \mathrm{~kW})$ to heat up the water to the desired temperature through the temperature controller. Nitrogen for purging was used when switching from electrolyzer mode to fuel cell mode and at system shutdown time at which the nitrogen supplies to both hydrogen and oxygen piping line using solenoid valve. The solenoid valves will open and allow nitrogen to flow through the fuel and oxidant. A schematic of the hydrogen system is shown in Figure 2.

The laboratory was equipped with a fuel cell test station capable of measuring the stack temperature, hydrogen and air flow rate measurement, and the stack operating current and voltage. The subsystem contains humidification bottles for the fuel cell mode to humidify the reactant gases. The humidification can be bypassed if a dry gas feed into the stack is desired. The gas flow rates are controlled manually by a set of valves for each side of the stacks. Moreover, a data acquisition system was incorporated to generate polarization curves and time history of the stacks performance, the temperature at various locations in the system, and the solar irradiation.

\section{System Modeling}

3.1. PV Module. The model given by Duffie and Beckman [17] was used to model the PV modules' current and voltage output. At fixed temperatures and solar radiation, the current-voltage characteristic of a PV module can be modeled using

$$
I=I_{L}-I_{D}=I_{L}-I_{o}\left(e^{\left(V+I R_{\mathrm{s}}\right) / a}-1\right)-\frac{V+I R_{s}}{R_{\mathrm{sh}}} .
$$

The power is given by

$$
P_{\mathrm{PV}}=I V .
$$

In most cases, the shunt current can be ignored because the shunt resistance is so high that the term goes to zero, particularly for monocrystalline solar cells, so (1) becomes

$$
I=I_{L}-I_{D}=I_{L}-I_{o}\left(e^{\left(V+I R_{s}\right) / a}-1\right)
$$




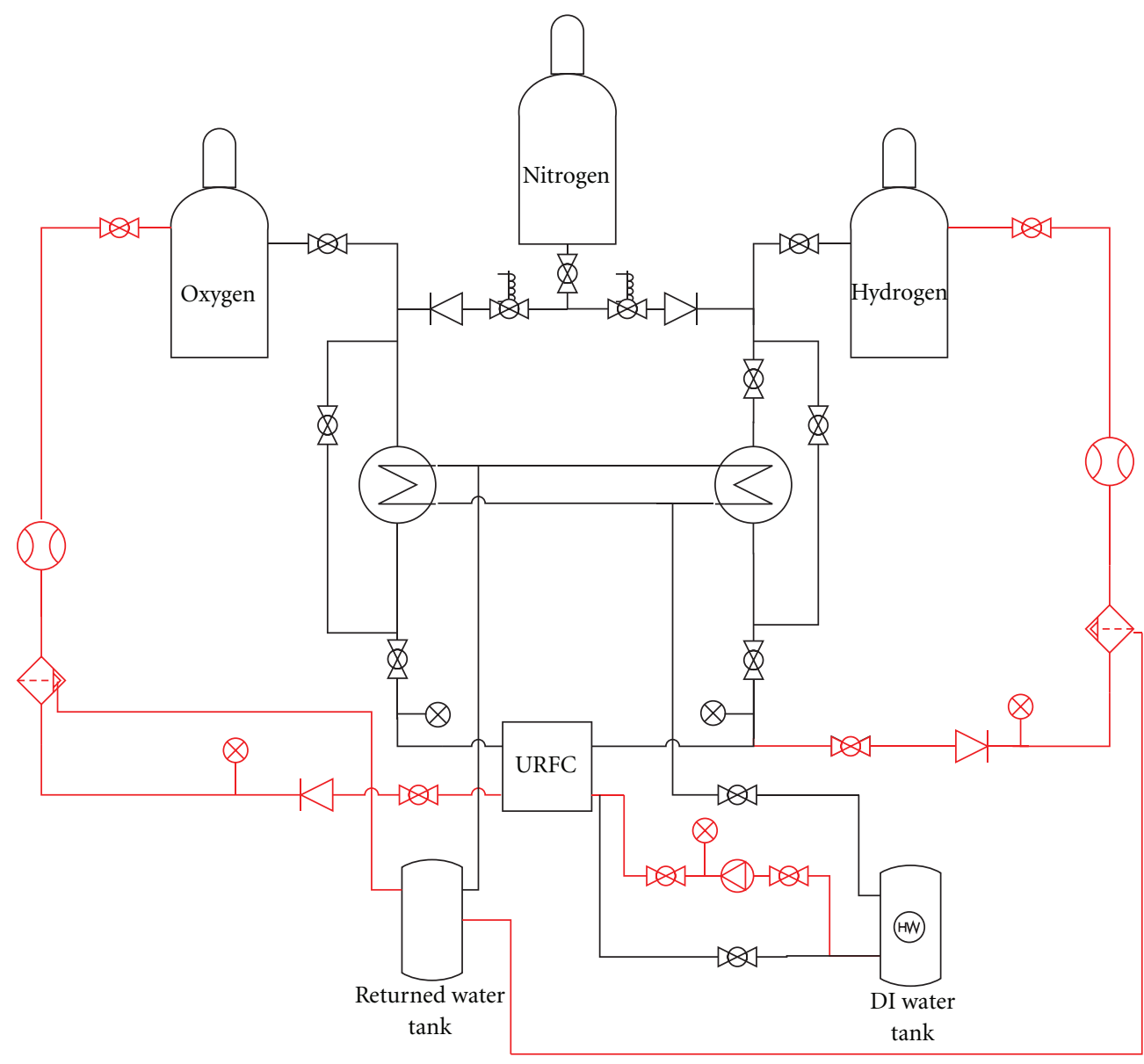
$\infty$ Ball valve
$\bowtie$ Check valve
-2- Flow meter
(3) Humidifier

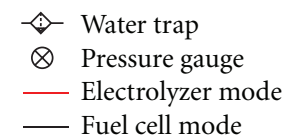
(«A) Water heater
Solenoid valve
$\otimes$ Pump

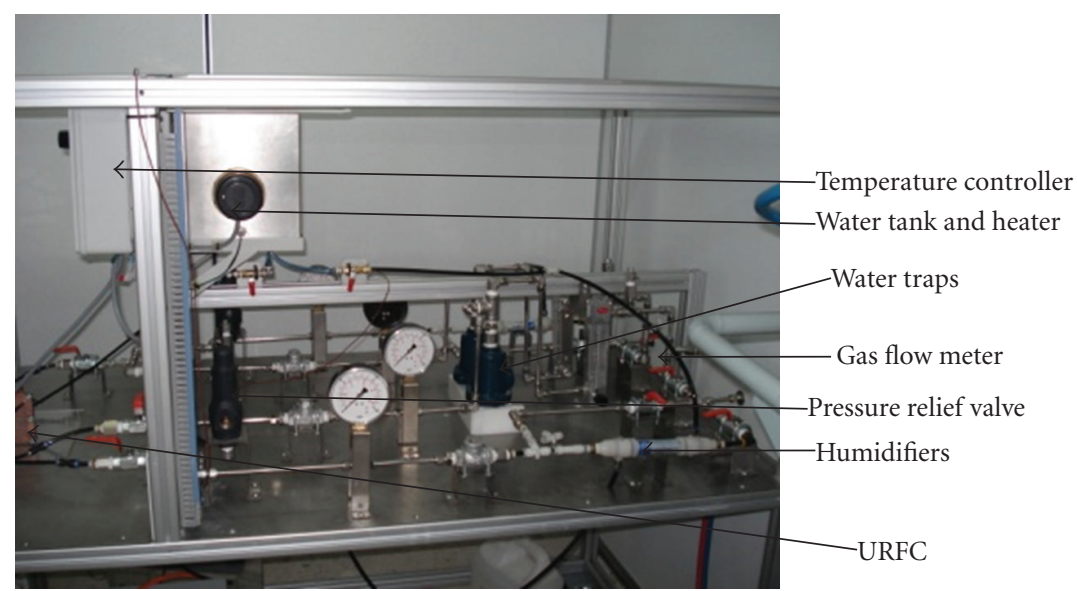

FIGURE 2: The hydrogen system prototype.

and in terms of voltage becomes

$$
V=a \cdot \ln \left(\frac{I_{L}-I+I_{o}}{I_{o}}\right)-I R_{s} .
$$

The values of $I_{L}, I_{o}, V_{\mathrm{oc}}$, and the parameter $a$ are functions of the cell temperature. The model presented by Duffie and
Beckman [17] was used to find these parameters and consequently the operating voltage at any load current.

3.2. Electrolyzer Mode. The electrode kinetics of an electrolyzer modeled using the semiempirical current-voltage relationships is presented by Ulleberg [18]. The basic form 
TABLE 1: Electrolyzer mode parameters.

\begin{tabular}{lcc}
\hline Parameter & Value & Unit \\
\hline$r_{1}$ & $9.5 \times 10^{-5}$ & $\Omega \cdot \mathrm{m}^{2}$ \\
$r_{2}$ & $-4.7 \times 10^{-7}$ & $\Omega \cdot \mathrm{m}^{2} \cdot{ }^{\circ} \mathrm{C}^{-1}$ \\
$s_{1}$ & 0.1689 & $\mathrm{~V}$ \\
$s_{2}$ & 0.0008 & $\mathrm{~V} \cdot{ }^{\circ} \mathrm{C}^{-1}$ \\
$s_{3}$ & $-1.33 \times 10^{-5}$ & $\mathrm{~V} \cdot{ }^{\circ} \mathrm{C}^{-2}$ \\
$t_{1}$ & 0.33 & $\mathrm{~m}^{2} \cdot \mathrm{A}^{-1}$ \\
$t_{2}$ & 5.48 & $\mathrm{~m}^{2} \cdot \mathrm{A}^{-1} \cdot{ }^{\circ} \mathrm{C}$ \\
$t_{3}$ & 242 & $\mathrm{~m}^{2} \cdot \mathrm{A}^{-1} \cdot{ }^{\circ} \mathrm{C}^{2}$ \\
\hline
\end{tabular}

of the $I-V$ curve is given by (5), and that curve varies for a given temperature:

$$
U_{\mathrm{el}}=U^{o}-\frac{R T}{n F} \ln \left(P_{\mathrm{H}_{2}} \cdot P_{02}^{0.5}\right)+\frac{r}{A} I+s \log \left(\frac{t}{A} I+1\right) .
$$

Ulleberg and Mørner [19] used the following equations to count the temperature dependence of the ohmic resistance $(r)$ and the overvoltage coefficients $(s$ and $t)$ :

$$
\begin{gathered}
t=t_{1}+\frac{t_{2}}{T}+\frac{t_{3}}{T_{2}}, \\
r=r_{1}+r_{2} T, \\
s=s_{1}+s_{2} T+s_{3} T^{2} .
\end{gathered}
$$

The electrolyzer used in this study had been tested under different operating temperatures, and with and without ohmic losses to predict the ohmic losses (as well as the rest of the losses). The results are then plotted, and, through curve fitting, the parameters can be found. Table 2 listed the overpotential parameters for the electrolyzer. Once the eight parameters for the electrolyzer mode were found, (5) can be used to describe the $I-U$ for the stack. Table 1 listed the electrolyzer mode parameters.

3.3. Fuel Cell Mode. The current-voltage characteristics of a PEM fuel cell used in this study are an empirical equation used by Ulleberg [20] that takes overvoltages due to activation into account. However, the concentration losses were neglected since the operating current density was lower than $200 \mathrm{~mA} / \mathrm{cm}^{2}$. The following equation was used to predict the fuel cell mode voltage as a function of the current density:

$$
U_{\mathrm{fc}}=U_{o}-b \log i-r i .
$$

The open-circuit voltage can be measured or calculated from

$$
U_{o}=E_{\mathrm{rev}}+b \log i_{o}
$$

Table 2 listed the real operation results for the URFC working on the fuel cell mode at two different cell temperatures and 1 bar pressure fully humidified hydrogen and oxidants.

In order to simulate the performance of the system, the electric and thermoelectric equations of each part of the system were solved using MATLAB code. The input parameters were the solar irradiation and location parameters

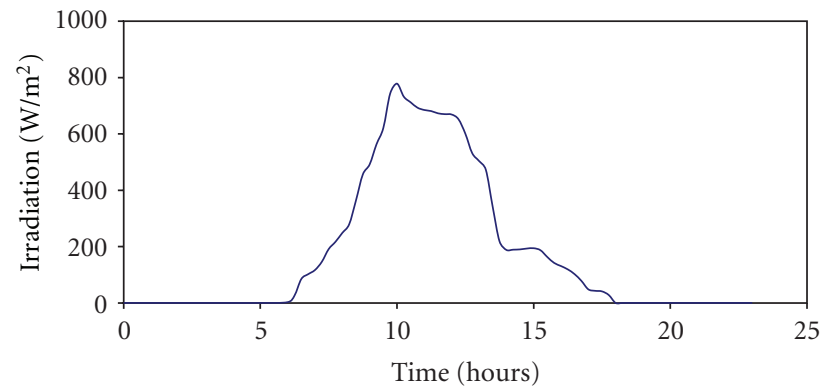

FIgURE 3: Solar irradiation for the selected day (November 19, 2009).

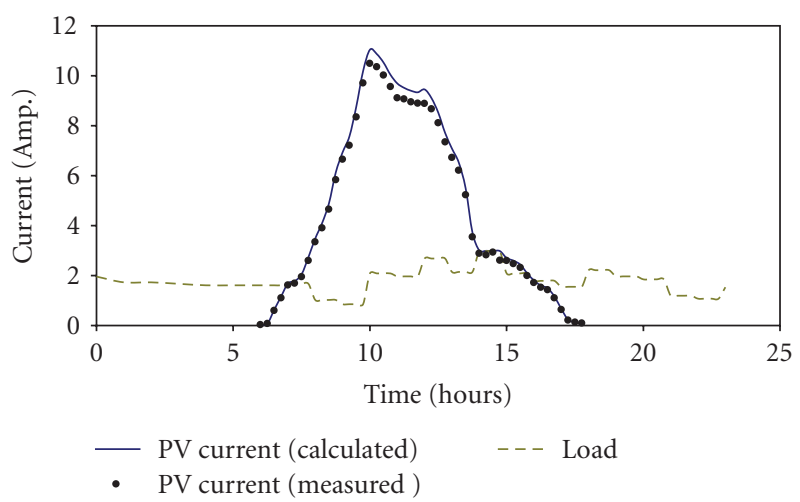

FIGURE 4: PV current output and load current for the selected day (November 19, 2009).

(whether data), proposed load profile, regenerative fuel cell specifications, and the hydrogen and oxygen tanks specifications. The DC/DC controller efficiency was set to $95 \%$.

\section{Results and Discussion}

Among the testing days, a relatively low solar radiation day was selected, on which the total daily radiation was about $4.1 \mathrm{kWh}$ (refer to Figure 3). The system first turned on the electrolyzer mode ELM to generate hydrogen. Figure 4 shows the measured and simulated PV current output and the current given to the load. Its clear to see that the current from the PV during the sunny hours was much higher than the load current, and therefore the excess current goes to the stack to generate hydrogen. The simulated and measured data was almost with relatively low error, especially at a low operating current, and slightly increased when the current increased due to nonconsiderable ohmic loses for the simulation data.

The electrolyzer current keeps increasing as the PV current increases and then decreases till reaching to zero at about 4 PM. At that time, the stack switched to fuel cell mode FCM after purging the stack with inert nitrogen. The fuel cell mode current is higher than the load current and the load voltage is $12 \mathrm{~V} \mathrm{DC}$, while the fuel cell mode voltage is less than $6 \mathrm{~V}$. Because of this the stack should generate a higher current to meet the power required for the load after 
TABLE 2: Fuel cell mode parameters.

\begin{tabular}{ccccccccc}
\hline & \multicolumn{3}{c}{ Oxygen } & \multicolumn{3}{c}{ Air } \\
$\mathrm{T},{ }^{\circ} \mathrm{C}$ & $\begin{array}{c}E_{\text {rev. }} \\
\mathrm{V}\end{array}$ & $\begin{array}{c}U_{0} \\
\mathrm{~V}\end{array}$ & $\begin{array}{c}b, \\
\mathrm{mV} / \mathrm{dec}\end{array}$ & $\begin{array}{c}i_{o}, \\
\mathrm{~mA} / \mathrm{cm}^{2}\end{array}$ & $\begin{array}{c}E_{\text {rev. }} \\
\mathrm{V}\end{array}$ & $\begin{array}{c}U_{o} \\
\mathrm{~V}\end{array}$ & $\begin{array}{c}b, \\
\mathrm{mV} / \mathrm{dec}\end{array}$ & $\begin{array}{c}i_{o}, \\
\mathrm{~mA} / \mathrm{cm}^{2}\end{array}$ \\
\hline 30 & 1.18 & 1.028 & 86.6 & 0.0016 & 1.17 & 0.972 & 91.1 & 0.0012 \\
70 & 1.17 & 0.999 & 71.8 & 0.0035 & 1.16 & 0.962 & 79 & 0.0028 \\
\hline
\end{tabular}

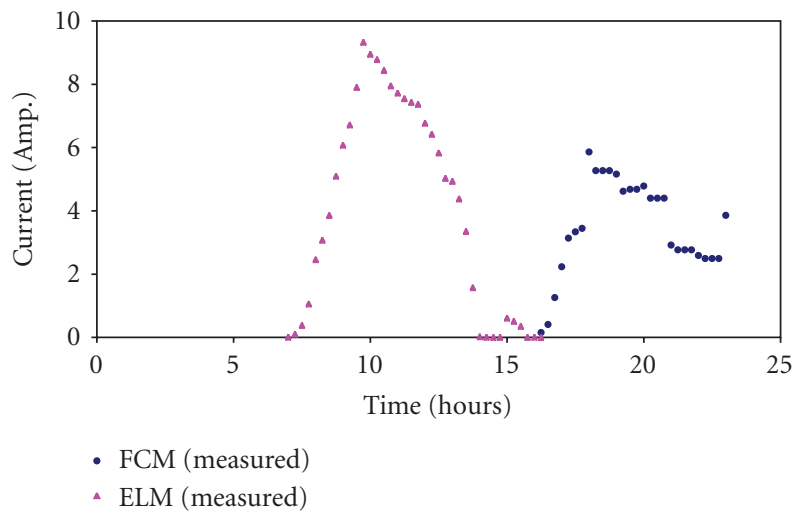

Figure 5: Fuel cell and electrolyzer mode measured current.

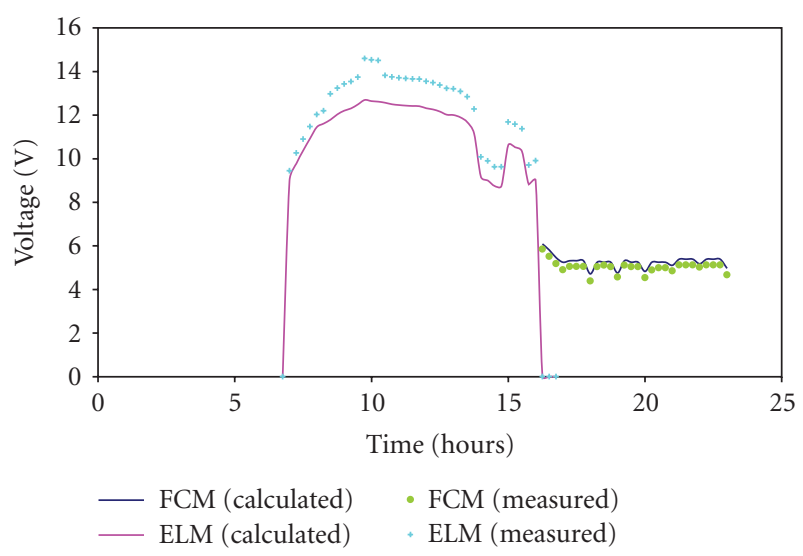

FIGURE 6: Fuel cell mode voltage and electrolyzer mode voltage.

DC/DC controls the voltage to the desired load amount. Figure 5 shows the stack current for the electrolyzer and fuel cell mode.

The Fuel cell and electrolyzer mode voltage are shown in Figure 6 . The voltage of the stack during the fuel cell mode is around $6 \mathrm{~V}$ ( 7 cells stack). The measured electrolyzer voltage was slightly higher than the simulated values because the PV output voltage was slightly higher than the electrolyzer required voltage. The bus bar current available at the system is either from the PV current or from the stack through the fuel cell mode. Figure 7 shows the bus bar current distribution for the selected day.

The variation of the stored hydrogen inside the hydrogen tank is shown in Figure 8. The initial pressure value was set at 1 bar. The simulation results showed acceptable predictable values comparing to the real data, with a RMS error of

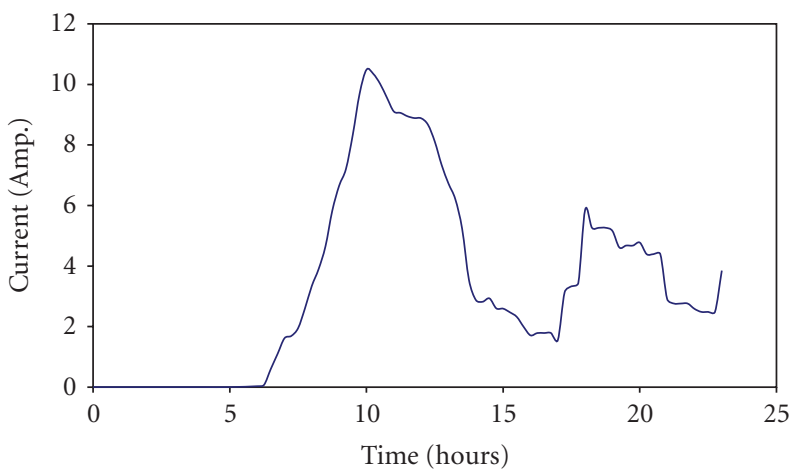

Figure 7: Measured fuel cell and electrolyzer mode bus available current.

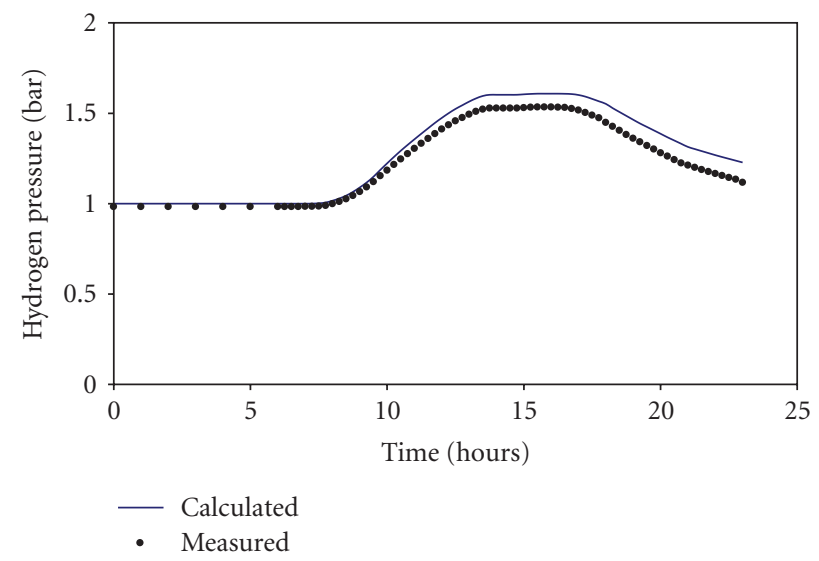

FIGURE 8: Simulated and measured hydrogen tank pressure.

0.07 bars. This was mainly because the gases were assumed to behave as an ideal gas and the real amount of the produced and consumed amount of hydrogen was not the same as the simulated values.

The summary of the full measured results for the selected day is shown in Figure 9 and all the results are listed in Table 3.

\section{Conclusion}

The following can be concluded from the current study.

(1) The load will be powered by the PV array at the solar time, and the extra power will go to the electrolyzer to produce hydrogen. After sunset, or at the time of low irradiation, this stored hydrogen will be used to power the load through the fuel cell. 
TABLE 3: Summary of the selected day measured and simulation results.

\begin{tabular}{|c|c|c|c|}
\hline System & Simulated & Measured & \\
\hline Solar input & 4.08 & 4.08 & $\mathrm{kWh} / \mathrm{m}^{2}$ \\
\hline PV output & 0.83 & 0.78 & kWh \\
\hline PV efficiency ${ }^{\mathrm{a}}$ & 10.3 & 9.7 & $\%$ \\
\hline User load & 0.37 & 0.37 & kWh \\
\hline PV to load ${ }^{\mathrm{b}}$ & 28.85 & 31.43 & $\%$ \\
\hline Load powered by $\mathrm{PV}^{\mathrm{c}}$ & 65.26 & 66.94 & $\%$ \\
\hline FCM power & 0.13 & 0.12 & kWh \\
\hline FCM operating hours & 7 & 7 & hr \\
\hline Total $\mathrm{H}_{2}$ consumed $^{\mathrm{d}}$ & 0.25 & 0.27 & kWh \\
\hline FCM energy efficiency ${ }^{\mathrm{e}}$ & 50.1 & 45.35 & $\%$ \\
\hline ELM power & 0.46 & 0.51 & kWh \\
\hline ELM operating hours & 9 & 9 & $\mathrm{hr}$ \\
\hline Total $\mathrm{H}_{2}$ produced & 0.39 & 0.35 & kWh \\
\hline ELM energy efficiency ${ }^{\mathrm{f}}$ & 84.48 & 68.98 & $\%$ \\
\hline Total system Efficiencyg & 4.55 & 4.55 & $\%$ \\
\hline Round trip efficiency ${ }^{\mathrm{h}}$ & 42.31 & 31.28 & $\%$ \\
\hline
\end{tabular}

${ }^{\mathrm{a}} \mathrm{PV}$ output to the solar input.

b(Load - Fuel cell mode power)/PV output.

c(Load - Fuel cell mode power)/load.

${ }^{\mathrm{d} B a s e d}$ on HHV for hydrogen.

${ }^{\text {e}}$ Fuel cell mode power to the hydrogen consumed.

${ }^{\mathrm{f}}$ Hydrogen produced to the electrolyzer mode power.

gLoad to the solar input.

${ }^{h}$ Fuel cell mode efficiency and electrolyzer mode efficiency.

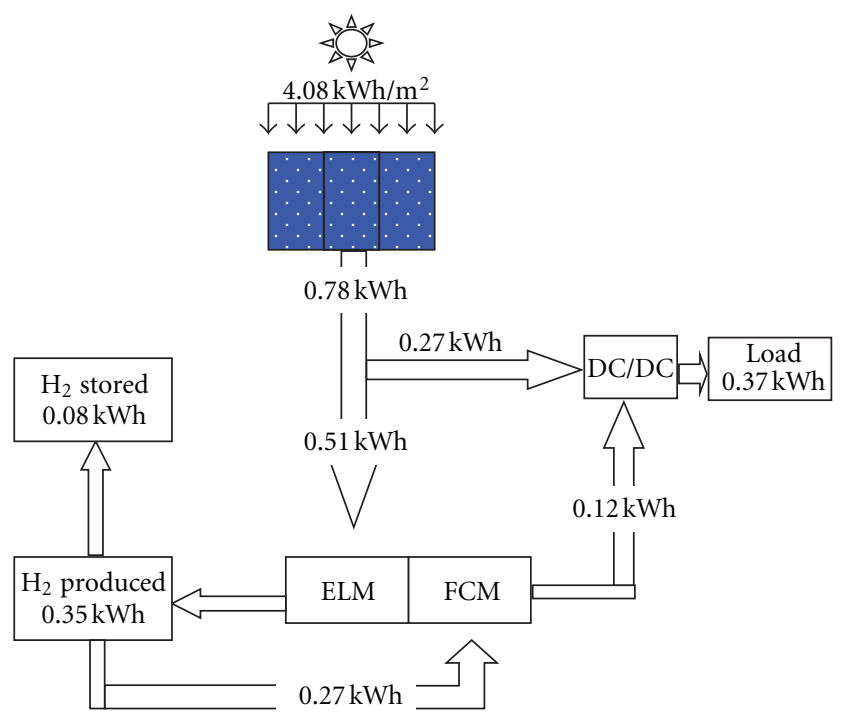

Figure 9: Summary of measured data for the selected day.

(2) Comparing the simulated results with measured data shows the ability of the cell modeling to predict the cell performance with an acceptable level of error. The difference between the measured and simulated data increased as the operating current increases.

(3) The performance of the stack works on electrolyzer or fuel cell mode was slightly lower when compared with the discrete electrolyzer and fuel cell, which is an expected result since the membrane electrode assembly catalysts were chosen based on compromise between fuel cell and electrolyzer mode performance.
Abbreviations
$a$ : Curve fitting parameter Volts
$b$ : Tafel constant $\mathrm{mV} / \mathrm{dec}$
E: Voltage $\mathrm{V}$ 
F: Faraday's constant, 96485 Amp · sec/mol

$G$ : Solar irradiance $\mathrm{W} / \mathrm{m}^{2}$

I: Current Amp

$I_{o}$ : Diode reverse saturation current Amp

$i$ : $\quad$ Current density Amp $/ \mathrm{cm}^{2}$

$N^{o}$ : Molar flow rate $\mathrm{mol} / \mathrm{sec}$

$N_{C}$ : No. of cell in the stack

$n$ : No. of electron in the reaction (2)

$P$ : Power W

$P$ : Partial pressure atm

$R:$ Resistance ohm

$R: \quad$ Gas constant $\mathrm{kJ} / \mathrm{kg} \cdot \mathrm{K}$

$r$ : Parameter related to ohmic resistance $\mathrm{ohm} \cdot \mathrm{m}^{2}$

$s$ : Coefficient for overvoltage $\mathrm{V}$

$t$ : Coefficient for overvoltage $\mathrm{m}^{2} / \mathrm{Amp}$

$T$ : Temperature K

$U$ : Fuel Cell or electrolyzer Voltages $\mathrm{V}$

$V:$ PV voltage $\mathrm{V}$.

\section{Subscripts}

$c:$ Cell
$D:$ Diode
el: Electrolyzer
fc: Fuel cell
$\mathrm{H}_{2}:$ Hydrogen
$L:$ Light
$\mathrm{O}_{2}:$ Oxygen
$o:$ Exchange current density
oc: Open circuit
$s:$ Series
sh: Shunt
sc: Short circuit
ref: Reference
rev: Reversible
$T:$ Tilted.

\section{Acknowledgments}

The authors would like to thank the Solar Energy Research Institute (SERI), Universiti Kebangsaan, Malaysia, for their invaluable support. Sincere gratitude should be sent to the Ministry of Science, Technology and Innovation (MOSTI), Government of Malaysia, for providing funds for the research under the IRPA Project no. 03-01-02-SF0329.

\section{References}

[1] K. Ro, "Two-loop controller for maximizing performance of a grid-connected photovoltaic-fuel cell hybrid power plant," in Electrical Engineering, Faculty of the Virginia Polytechnic Institute and State, Blacksburg, Va, USA, 1997.

[2] T. A. Nergaard, "Modeling and control of a single-phase, $10 \mathrm{~kW}$ fuel cell inverter," in Electrical Engineering, Faculty of the Virginia Polytechnic Institute and State, Blacksburg, Va, USA, 2002.

[3] J. Pettersson, B. Ramsey, and D. Harrison, "A review of the latest developments in electrodes for unitised regenerative polymer electrolyte fuel cells," Journal of Power Sources, vol. 157, no. 1, pp. 28-34, 2006.

[4] M. Fischer, "Review of hydrogen production with photovoltaic electrolysis systems," International Journal of Hydrogen Energy, vol. 11, no. 8, pp. 495-501, 1986.

[5] J. M. Vidueira, A. Contreras, and T. N. Veziroglu, "PV autonomous installation to produce hydrogen via electrolysis, and its use in FC buses," International Journal of Hydrogen Energy, vol. 28, no. 9, pp. 927-937, 2003.

[6] M. Park, D. H. Lee, and I.-K. Yu, "PSCAD/EMTDC modeling and simulation of solar-powered hydrogen production system," Renewable Energy, vol. 31, no. 14, pp. 2342-2355, 2006.

[7] M. Park, H. R. Seo, D. H. Lee, and I. K. Yu, "Characteristics analysis of a PV-AF-SPE system under several irradiation conditions," Renewable Energy, vol. 34, no. 3, pp. 499-503, 2009.

[8] S. Galli and M. Stefanoni, "Development of a solar-hydrogen cycle in Italy," International Journal of Hydrogen Energy, vol. 22, no. 5, pp. 453-458, 1997.

[9] L. Hedström, C. Wallmark, P. Alvfors, M. Rissanen, B. Stridh, and J. Ekman, "Description and modelling of the solar-hydrogen-biogas-fuel cell system in GlashusEtt," Journal of Power Sources, vol. 131, no. 1-2, pp. 340-350, 2004.

[10] H. Abaoud and H. Steeb, "The German-Saudi hysolar program," International Journal of Hydrogen Energy, vol. 23, no. 6, pp. 445-449, 1998.

[11] K. Voss, A. Goetzberger, G. Bopp, A. Häberle, A. Heinzel, and H. Lehmberg, "The self-sufficient solar house in Freiburgresults of 3 years of operation," Solar Energy, vol. 58, no. 1-3, pp. 17-23, 1996.

[12] N. Lutfi and T. N. Veziroğlu, "Solar-hydrogen demonstration project for Pakistan," International Journal of Hydrogen Energy, vol. 17, no. 5, pp. 339-344, 1992.

[13] A. M. Chaparro, J. Soler, M. J. Escudero, E. M. L. De Ceballos, U. Wittstadt, and L. Daza, "Data results and operational experience with a solar hydrogen system," Journal of Power Sources, vol. 144, no. 1, pp. 165-169, 2005.

[14] M. Little, M. Thomson, and D. Infield, "Electrical integration of renewable energy into stand-alone power supplies incorporating hydrogen storage," International Journal of Hydrogen Energy, vol. 32, no. 10-11, pp. 1582-1588, 2007.

[15] L. A. Torres, F. J. Rodríguez, and P. J. Sebastian, "Simulation of a solar-hydrogen-fuel cell system: results for different locations in Mexico," International Journal of Hydrogen Energy, vol. 23, no. 11, pp. 1005-1009, 1998.

[16] T. Markvart, Solar Electricity, John Wiley \& Sons, New York, NY, USA, 1994.

[17] J. A. Duffie and W. A. Beckman, Solar Engineering of Thermal Processes, John Wiley \& Sons, New York, NY, USA, 2nd edition, 1991.

[18] O. Ulleberg, "Modeling of advanced alkaline electrolyzers: a system simulation approach," International Journal of Hydrogen Energy, vol. 28, no. 1, pp. 21-33, 2003.

[19] O. Ulleberg and S. O. Mørner, "TRNSYS simulation models for solar-hydrogen systems," Solar Energy, vol. 59, no. 4-6, pp. 271-279, 1997.

[20] O. Ulleberg, Stand-alone power systems for the future: optimal design, operation \& control of solar-hydrogen energy systems [Ph.D. thesis], Norwegian University of Science and Technology, Trodheim, Norway, 1998. 


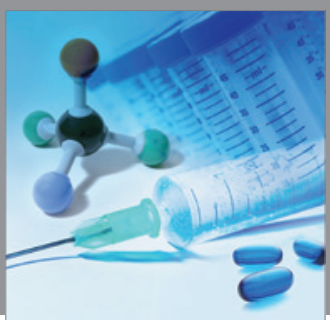

International Journal of

Medicinal Chemistry

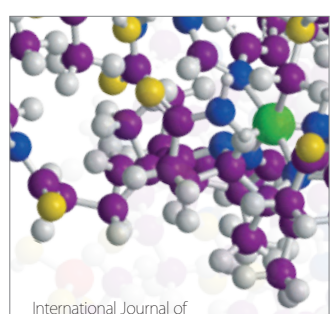

Carbohydrate Chemistry

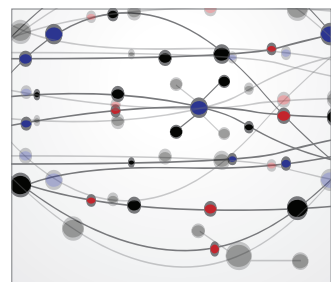

The Scientific World Journal
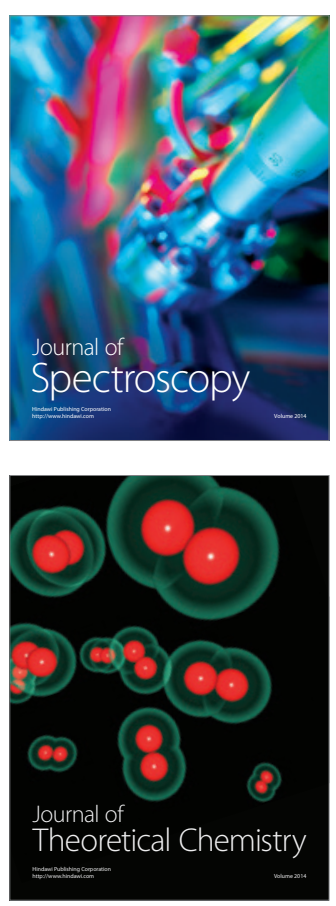
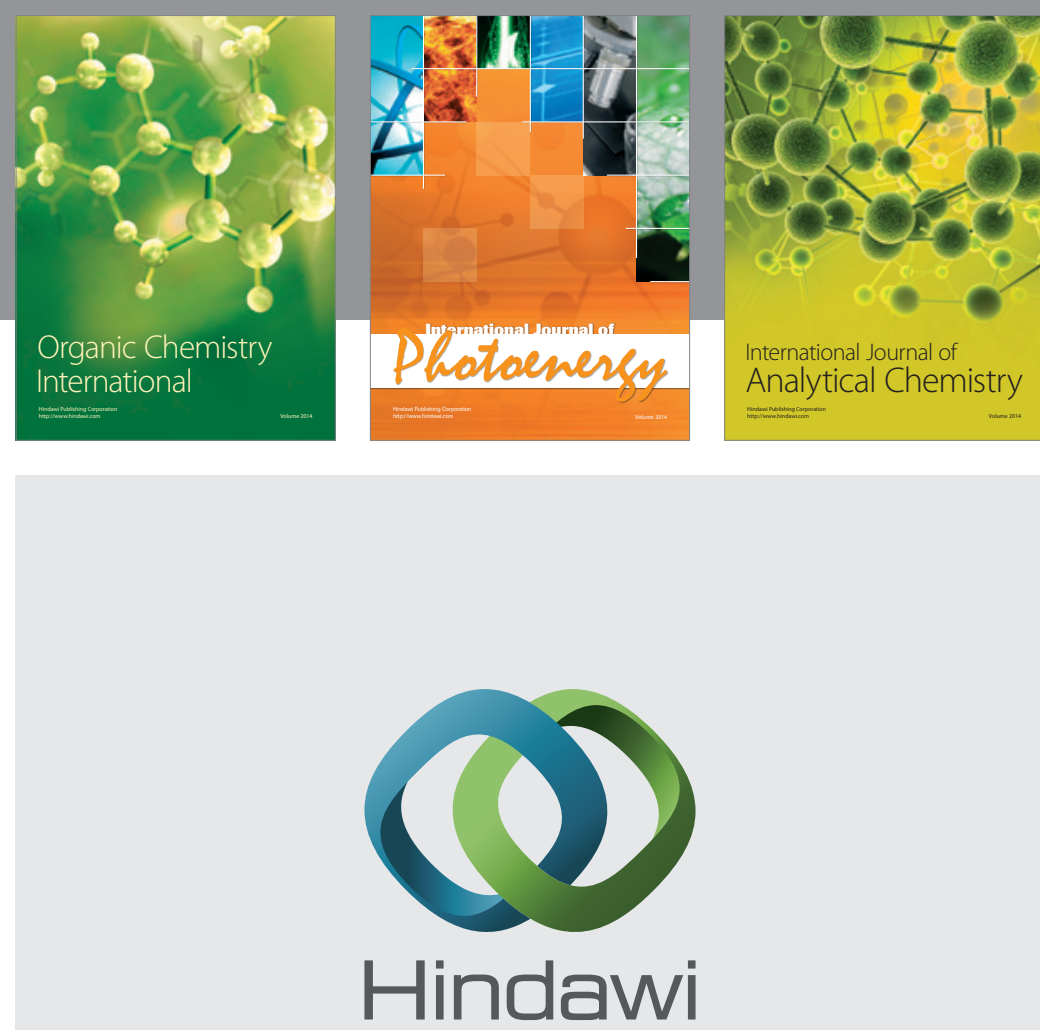

Submit your manuscripts at

http://www.hindawi.com
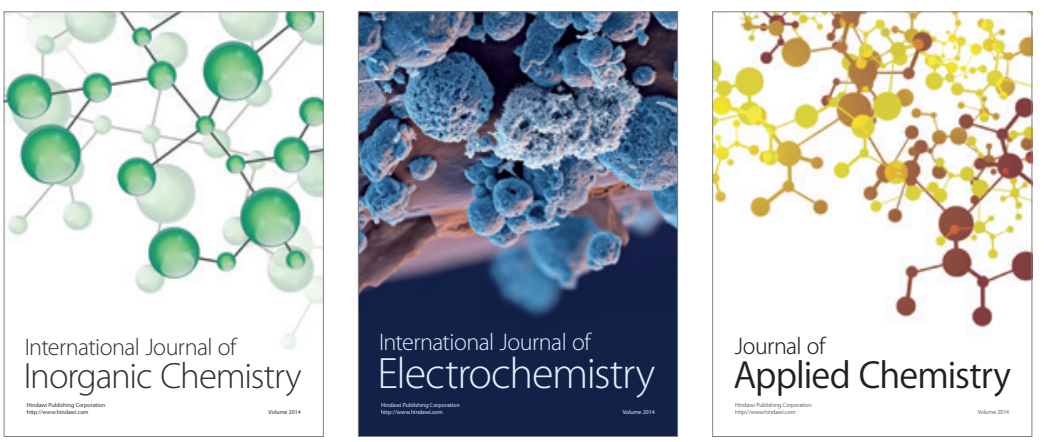

Journal of

Applied Chemistry
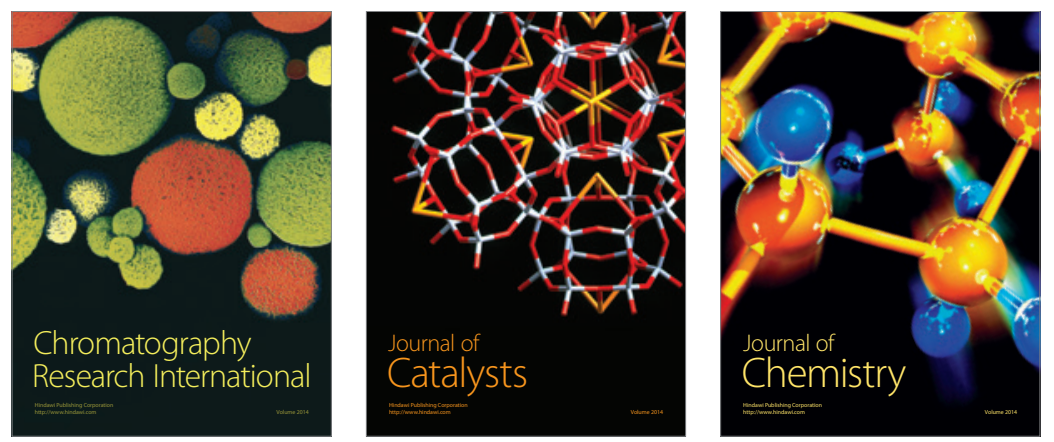
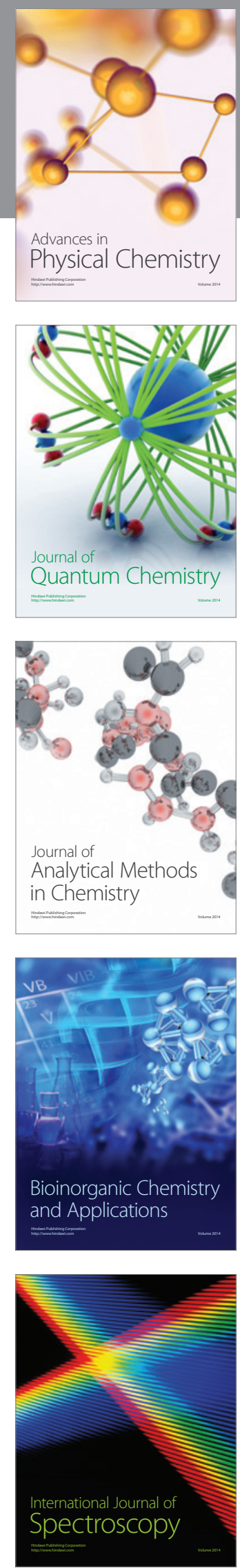